\title{
Strategy Map Cascading Method for Performance Management Implementation
}

\author{
Danny Indi Purihita Prasetyo \\ Accounting Master Program \\ Economics and Business Faculty \\ University of Indonesia \\ email: indi.danny@yahoo.co.id \\ Thomas Honggo Secokusumo \\ Accounting Master Program \\ Economics and Business Faculty \\ University of Indonesia \\ email: secokusumo@yahoo.com
}

\begin{abstract}
The balanced scorecard is commonly used to manage and measure company performance. When implemented, a set of strategies are built to take competitive advantage of competitors and to meet long-term goals. A strategy map lays out the steps needed for a company to execute and manage its strategy. It is important for a company to cascade strategies to all levels of the organization to ensure that everyone understands their roles and responsibilities. The purpose of this research is to evaluate the cascading process of a company's strategy map process via a case study and to compare it to common KaplanNorton methods.
\end{abstract}

Keywords-balanced scorecard, performance management, strategic management, strategy map, cascading

\section{INTRODUCTION}

A company can be described as a series of tool-driven activities used to create a profit [1]. Every for-profit company aims to provide endless revenue to the owners and stakeholders. The accounting department accommodates that goal by publishing financial reports using principles and standards that enable investors and customers to make the right decisions about supporting the company. The balanced scorecard (BSC) strategydevelopment method was introduced by Robert S. Kaplan and David P. Norton [2][3] and has been widely applied by worldwide companies. The advantage of the BSC method rests in its ability to connect a company's long-term goals to its short-term plans and operations.

PT XYZ, an Indonesian hotel chain, uses the BSC approach as their internal performance management system. The system accommodates their need to grow the business while maintaining excellent current operations. Corporate management also understands that BSC is useful only if every member of the company is involved and committed. Thus, they have cascaded the process, including its key performance indicators (KPI), goals, and objectives to every hotel under their purview. Cascading is managed by a corporate-level strategic management office (SMO) that reviews the scorecard, reports results, and implements lessons learned.

This study reviews PT XYZ's BSC operation and its cascading mechanism to evaluate its proper use.

\section{THEORETICAL REVIEW}

\section{A. Strategic Management}

Strategic management is defined as an organization's process and approach to specifying objectives, developing policies, programs, paradigms and plans to achieve these objectives, and allocating resources to implement them [4]. Pearce and Robinson (2009) [5] defined strategic management as the set of decisions and actions that result in the formulation and implementation of plans designed to achieve a company's objectives. They also showed that strategic management comprised nine critical tasks for managing strategy:

- Formulate the company's mission, including its purpose, philosophy, and goals.

- Analyze internal conditions and capabilities.

- Assess the external environment, including the competition.

- Analyze options by matching company resources with the external environment.

- Identify the most desirable options by evaluating each option against the company's mission/vision.

- Select a set of long-term objectives and grand strategies to achieve the most desirable end state.

- Develop annual objectives and short-term strategies that are compatible with the high-level strategy.

- Implement strategic choices by budgeting, allocating, matching plans to resources, managing structures, leveraging technologies, and applying reward systems.

- Evaluate success and use results as input to future decision making processes.

Based on the literature, strategic management is found to be the process by which a firm formulates, manages, and implements its strategy [6]. Wheelen [7] listed several advantages of applying strategic management, including maintaining a clearer outlook for the company, elevating the most crucial issues to the top, and gaining a better understanding of changing business requirements. 
Therefore, we can infer that strategic management is a set of measurable actions and decisions that are preceded by a series of analytical processes. Strategic management is an ever-expanding field, because the applied system of management and measurement impacts organizational dynamics. To succeed in the modern age, companies must measure and manage strategy [8]. In the past, most performance measurements relied purely on financial indicators. This reflects the $19^{\text {th }}$-century mindset of the industrial revolution. However, that model emphasized short-term financial performance and generally ignored the company's long-term growth.

\section{B. BSC}

BSC is a framework for integrating various measures derived from corporate strategy [8].It is one of the most popular tools used by organizations to manage performance. Many see BSC as the missing link between an organization's long-term goals and its daily operational activities [9]. BSC was popularized by Robert Kaplan, an accounting professor at the Harvard Business School. He and David Norton, president of Renaissance Solutions, Inc., promulgated the method to not only manage firm performance, but to also clarify and generate consensus, communicate to the entire company, align departmental and personal goals, link strategic and long-term goals with annual budgets, identify and align strategic initiatives, perform periodic and systematic reviews, and gain feedback and lessons learned.

As mentioned BSC looks beyond finances at customers, internal business processes, learning, and growth. In Norton [8], the author described the role of these perspectives. The financial perspective presents a firm's economic status as a consequence of actions and decisions taken. The measure of financial performance illustrates whether the company's strategy, implementation, and execution have impacted the status. A customer perspective provides an understanding of the value proposition offered by the company. Thus, it is assumed that success in providing maximum added value promotes the financial value of the company. The internal business process perspective helps identify various crucial internal activities that allow the company to provide an attractive value proposition, provide maximum satisfaction to customers and meet the financial expectations of the shareholders. The learning and growth perspective focuses on the infrastructure, culture, and knowledge that must be prepared by the company to enable growth and long-term success. Furthermore, BSC describes the cause-effect relationship between one perspective and another. Drivers, lead perspectives, and other items are considered as results (lag), as shown in Fig. 1 .

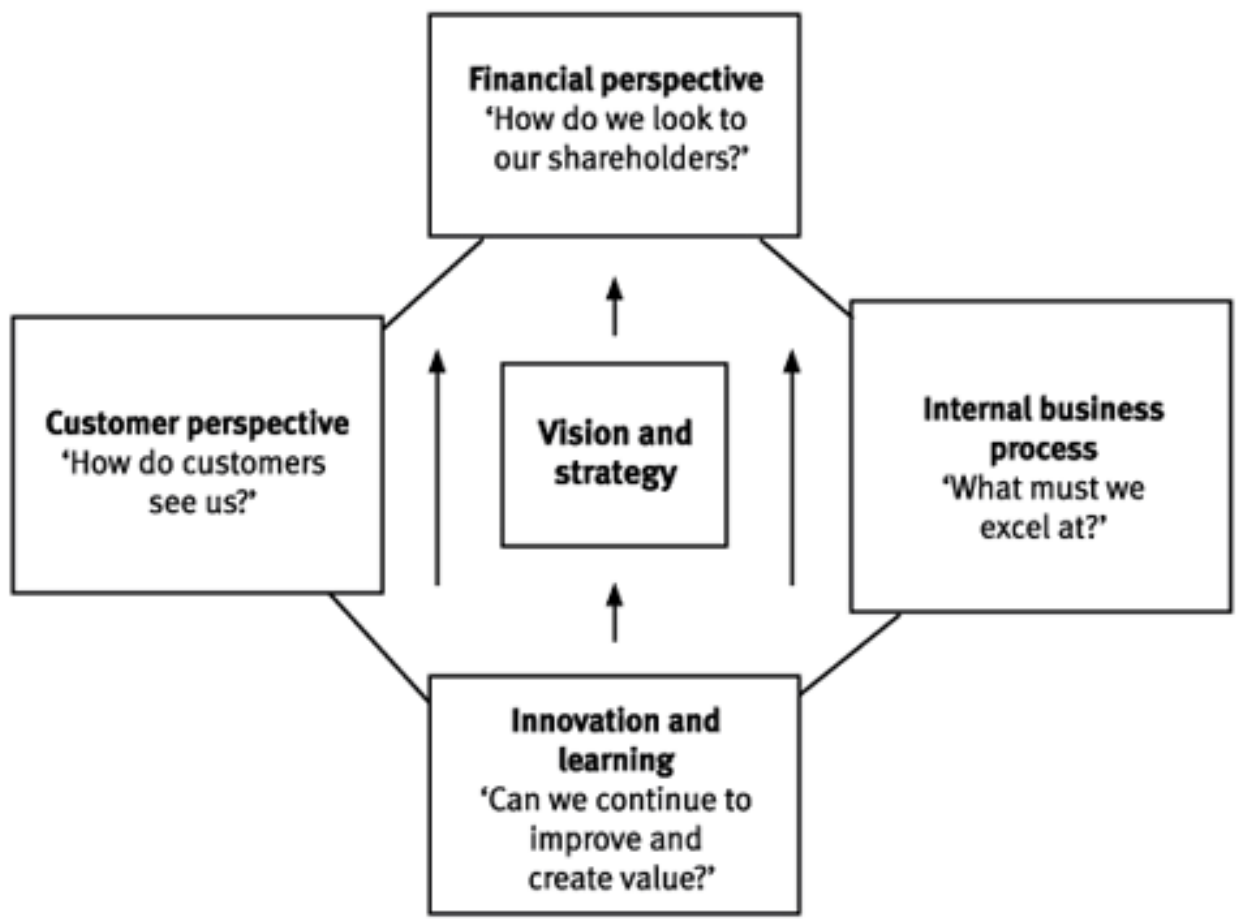

Fig. 1. Relationship between the four BSC perspectives.

Source: Kaplan Financial Limited, 2012

\section{Strategy Map}

A strategy map provides a detailed picture of the company's strategy from single perspective, so that it can offer focus and clarity to stakeholders. That said, multiple approaches can be used to formulate strategy. The strategy map will help organize and manage the process so that objectives can be determined and results can be assessed. Norton [10] stated that the strategy map was structured around several principles: strategy as a counterweight to conflicting priorities; strategy as value added to customers; value as a product of internal business processes; strategy as a series of complementary themes; and value resulting from alignment of intangible assets. See Fig. 2. 


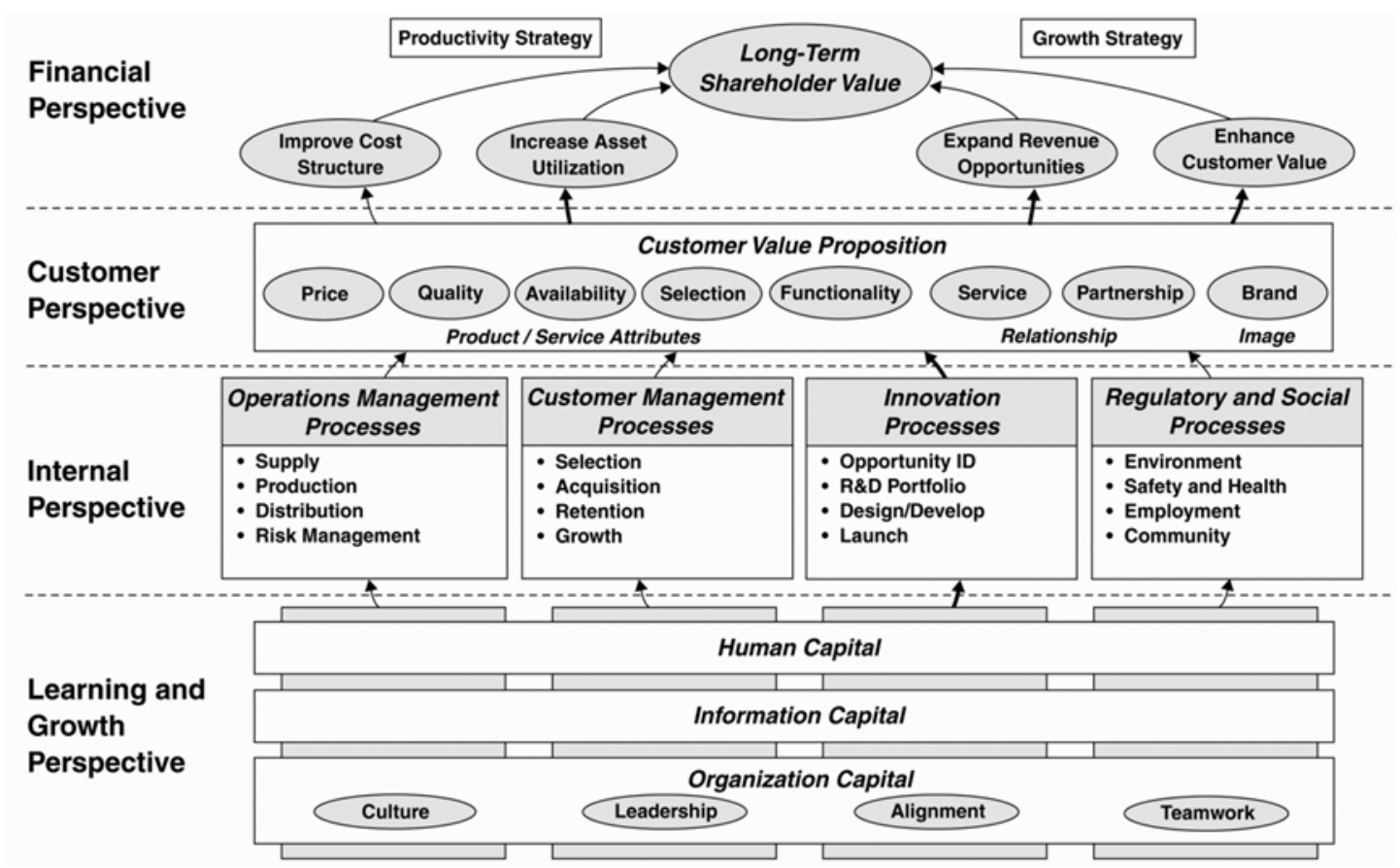

Fig. 2. Strategy map describes how strategies increase corporate value.

Source: Robert S. Kaplan \& David P. Norton, Strategy Maps : 2004

\section{Alignment}

Norton [11] also stated that a company needs five key components to drive the successful implementation of a strategy: mobilization, strategy translation, organizational alignment, employee motivation, and corporate governance. Alignment is considered a source of economic value. Through alignment, a company can serve their customers more thoroughly using their resources more efficiently, ultimately increasing the value of the company itself. Results are achieved, because a key point of alignment is ensuring all levels management and employees understand their positions, roles, and contributions within the company.

Norton [11] divided the process of aligning organizations into three types of alignment: vertical, horizontal, and external.

\section{E. Cascading}

Cascading helps align strategy by promulgating the information/policy from the top level to all subordinate organizations. Cascading is generally done via top-down and bottom-up approaches. Top-down cascading is common in companies with business units that share the same business character and market. The scorecard is determined at the top level for use on all business units. All parameters are the same for both the parent and child organization. Thus, the scorecard also serves as a communication tool for strategy and a measuring tool for performance.

There are several advantages of using a top-down approach. First, it is easiest. All strategic maps and objectives can be quickly and easily promulgated and used. Second, it improves strategic communications. Every strategy needs to be communicated to all parties to ensure identical understanding. Specific media are not required.
Third, having the same number of assessment parameters increases the spirit of competition. It also improves the learning for each unit via internal sharing and comparisons. The top-down approach also has some shortcomings, such as the lack of opportunities for business units to develop their own methods. Authoritarian systems can sometimes encounter rejection from subordinate business units.

The bottom-up approach is typically used by companies that have heterogeneous business units. With this method, a scorecard is set by each, who aligns theirs to the corporate strategy map. Once accepted by the parent company, the scorecard becomes a written contract between the parent and the business unit. Subsequently, the scorecard is used to measure heterogeneous performance.

\section{RESEARCH METHODOLOGY}

This study was conducted using primary data sourced from internal corporate work documents at PT XYZ, a non-listed company with more than 100 hotels throughout Indonesia. Data collection relied on paper documentation, observation, and interviews. This was followed by theoretical analysis and a comparison to actual company conditions.

\section{RESUlTS}

A strategic map is an illustration of the cause-effect relationships amongst documented perspectives. A strategic initiative undertaken to fulfill learning and growth and internal business process KPIs could also result in the achievement of customer-related or financial benefits. This cause-effect relationship is not found on PT XYZ's strategy map. The problem derives from their view of the customer's perspective. Based on theory, a customer perspective should describe the customer value proposition or the value offered by the company to customers when they consume products or services produced by the 
company. On the PT XYZ strategy map, the only thing describing customer value simply says, "provide excellent service." It is not measurable. Other objectives related to yield, market share, and increasing customer numbers are company expectations and not a value offered to customers. See Fig.

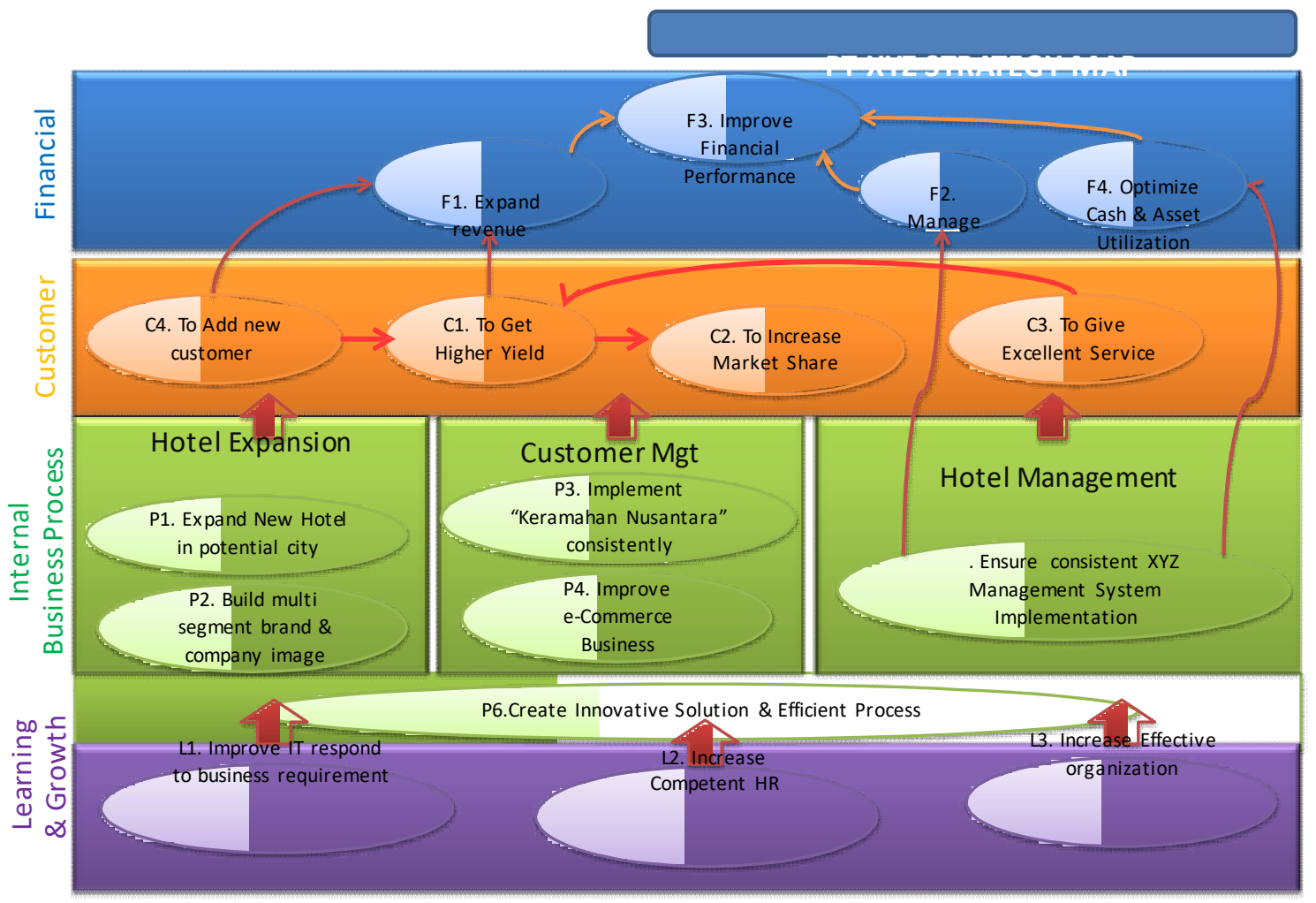

Fig. 3. PT XYZ existing strategy map.

Source: Reprocessed from PT XYZ Internal Document

The PT XYZ strategy map is not appropriately set in accordance with applicable rules. Thus, it cannot be used as the basis for cascading strategy to subordinate units. Therefore, it is necessary that they prepare a new strategy map. The new map should focus on customer perspectives by clarifying the value propositions. A clearly proposed value proposition will describe the causal relationships on the PT XYZ strategy map.

Kaplan and Norton noted that the value proposition could be divided into four segments: best total cost, which offers value in the form of economic price superiority; product leadership, which offers products and services superior to similar competitors; complete customer solution, which provides products and services tailored to customer needs; and lock-in, which leverages barriers discouraging customers from turning away.

Based on an analysis of PT XYZ's company vision, they aim to become the preferred hotel chain in Indonesia and, eventually, Southeast Asia. Based on interviews and observations, we found that their main advantage was consistently high-quality service delivered to customers. Thus, customers feel comfortable and will likely choose the PT XYZ chain as their primary market solution. PT $\mathrm{XYZ}$ clearly focuses on the product leadership segment, where the service provided has specific advantages not attainable by similar competitors.

\section{DISCUSSION}

To improve their cascading process, PT XYZ should rearrange their strategy map and build a grand strategy to achieve their company's vision. Thus, their goal of becoming the most preferred hotel-chain in Indonesia requires the assurance of high-quality services offered to guests by implementing service and employee behavior standards, serving tasty high quality food as a trademark, providing easy access to their transaction system, and making the strategy seamless for more than 100 hotels. Meanwhile, their strategy to become the largest hotel-chain in Indonesia and Southeast Asia requires consistent and value-added hotel expansion. To ensure delivery of their value proposition to their customers, they should implement a performance management system with procedures to ensure their service consistently meets the highest levels of standards. Then, they should create a new strategy map. $\quad$ See 


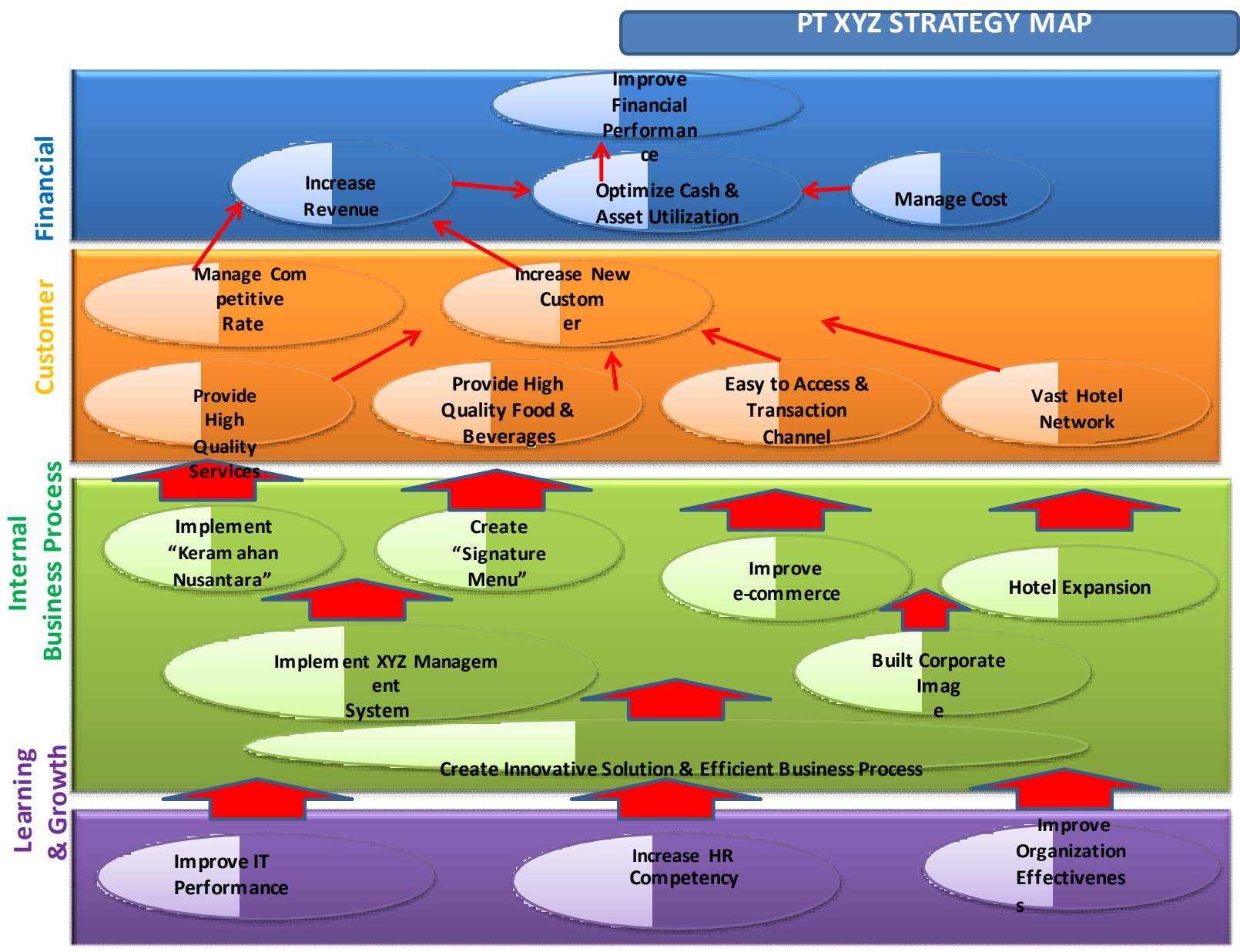

Fig. 4. PT XYZ Strategy Map Recommendation

In accordance with the product-leadership theme, a customer perspective should be established to measure the quality and value of service, food, easy access, transactions, and multi-hotel standardization. Several business processes are needed to provide better value to the customer. These processes include the application of the

philosophy of "archapeligo hospitality," the implementation of a hotel management system, and the creation of a signature menu for food services. The company should also improve their e-commerce presence to provide easy access to transactions. The company should build a strategy for hotel expansion to increase their service area and availability. They should also rebuild their company image by ensuring that all value offered is well received by customers. Furthermore, they should create an innovative business solution to support these changes with efficient processes. All corporate-level strategic objectives and KPIs are found in Tables I through IV.

TABLE I. PT XYZ Strategy MaP, FinANCial Perspective ReCOMmendation

\begin{tabular}{|c|c|c|c|c|}
\hline \multirow{13}{*}{ 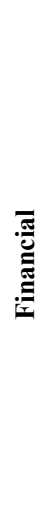 } & \multicolumn{2}{|r|}{ Strategic Objectives } & KPI & How To Calculate \\
\hline & \multirow{4}{*}{ F1 } & \multirow{4}{*}{ Increase Revenue } & Total Revenue & Total Revenue \\
\hline & & & Room Revenue & Room Revenue \\
\hline & & & Food and Beverage Revenue & Food \& Beverage Revenue \\
\hline & & & Other Revenue & $\begin{array}{l}\text { Other Revenue Beside Room, Food \& } \\
\text { Beverages }\end{array}$ \\
\hline & & & Operating Expense & $\begin{array}{c}(\text { Room Exp + F\&B Exp + Other Exp) / } \\
\text { Total Revenue x } 100 \%\end{array}$ \\
\hline & F2 & Manaoe Cost & Room Expense & Room Exp /Room Rev x 100\% \\
\hline & $\mathrm{F} 2$ & Mranage Cost & Food Expense & Food Exp / Food Rev x 100\% \\
\hline & & & Beverage Expense & Bev Exp /Bev Rev x $100 \%$ \\
\hline & & & Other Exp & Other Exp / Total Rev x 100\% \\
\hline & F3 & Improve Financial Performance & GOP Margin & Opt Profit / Total Revenue x 100\% \\
\hline & & & Net Opt Cash Flow & Total Cash In - Operational Cash Out \\
\hline & F4 & Cash Optimalization \& Asset Utilization & AR Days & $\begin{array}{l}\text { (Beginning Balance AR + Ending Balance } \\
\mathrm{AR} / 2 \text { ) / Total Gross Rev } \mathrm{x} \text { days in month }\end{array}$ \\
\hline
\end{tabular}


TABLE II. PT XYZ Strategy MaP, Customer Perspective Recommendation

\begin{tabular}{|c|c|c|c|c|}
\hline \multirow{15}{*}{ 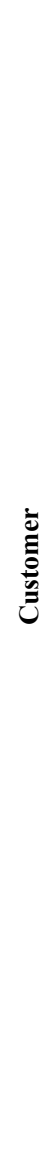 } & & Strategic Objectives & KPI & How To Calculate \\
\hline & \multirow{4}{*}{$\mathrm{C} 1$} & \multirow{4}{*}{ Increase Customer } & Occupancy Rate & Total Room Sold / Total Room Available x 100\% \\
\hline & & & Number of Membership & Number of Guest Apply For Membership \\
\hline & & & Number of Guest - Travel Agent & Number of Guest From Travel Agent \\
\hline & & & Number of Guest - Company & Number of Guest From Corporate Account \\
\hline & & \multirow{2}{*}{ Manage Competitive Rate } & Average Room Rate & Total Room Revenue / Total Room Sold \\
\hline & $\mathrm{CL}$ & & Market Price Index & Room Rate / Competitor's Average Room Rate \\
\hline & \multirow{3}{*}{$\mathrm{C} 3$} & \multirow{3}{*}{ Provide High Quality Services } & Customer Satisfaction Index & Guest Survey \\
\hline & & & Account Satisfaction Index & Corporate \& Travel Agent Survey \\
\hline & & & Repeater Guest & Number of Guest Make Repeat Check In \\
\hline & \multirow[b]{2}{*}{$\mathrm{C} 4$} & \multirow{2}{*}{$\begin{array}{c}\text { Provide Tasty \& High Quality Food \& } \\
\text { Beverages }\end{array}$} & Customer Satisfaction Index & Guest Survey \\
\hline & & & Account Satisfaction Index & Corporate \& Travel Agent Survey \\
\hline & \multirow{2}{*}{$\mathrm{C} 5$} & \multirow{2}{*}{ Easy Access \& Transaction } & $\begin{array}{l}\text { Reservation } \\
\text { Contribution }\end{array}$ & Online Room Reveue / Total Room Sales \\
\hline & & & Availability of Pick Up Services & Total Pick Up Vehicle / Total Hotel \\
\hline & C6 & Vast Hotel Network & Number of Hotel Operated & $\begin{array}{l}\text { No. of Hotel Beginning Year }+ \text { No. of Hotel } \\
\text { Opened }\end{array}$ \\
\hline
\end{tabular}

TABLE III. PT XYZ Strategy MaP, InTERnAl Business Process Perspective ReCommendation

\begin{tabular}{|c|c|c|c|c|}
\hline \multirow{11}{*}{ 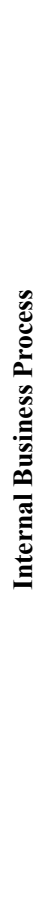 } & \multicolumn{2}{|r|}{ Strategic Objectives } & KPI & How To Calculate \\
\hline & P1 & Hotel Expansion & Number of New Hotel & Number of Hotel Opened \\
\hline & \multirow{3}{*}{$\mathrm{P} 2$} & \multirow{3}{*}{ Built Corporate Image } & $\begin{array}{l}\text { Number of Publication For Existing } \\
\text { Hotel }\end{array}$ & Number of Publication in 1 Year \\
\hline & & & Number of Publication For New Hotel & Number of Publication in 1 Year \\
\hline & & & $\begin{array}{l}\text { Number of Publication For "Signature } \\
\text { Menu" }\end{array}$ & $\begin{array}{l}\text { Number of Publication For "Signature Menu" } \\
\text { in } 1 \text { Year }\end{array}$ \\
\hline & P3 & Implement "Keramahan Nusantara" & $\begin{array}{l}\text { "Keramahan Nusantara" Implementation } \\
\text { Index }\end{array}$ & Keramahan Nusantara Audit Score \\
\hline & $\mathrm{P} 4$ & Improve e-commerce & E-Commerce Department Realization & \\
\hline & P5 & Implement "XYZ Management System" & $\begin{array}{l}\text { XYZ Management } \\
\text { Implementation Index }\end{array}$ & "XYZ Management System" Audit Score \\
\hline & P6 & Creating "Signature Menu" & Number of "Signature Menu" & Number of New "Signature Menu" in 1 year \\
\hline & \multirow{2}{*}{ P6 } & \multirow{2}{*}{$\begin{array}{l}\text { Create Innovative Solution \& Efficient } \\
\text { Business Process }\end{array}$} & NQI & Economic Value From Innovation Activity \\
\hline & & & Number of Innovation & Number of Innovation Created in 1 year \\
\hline
\end{tabular}


TABLE IV. PT XYZ StRATEgy MaP, LEARNING \& GROWTH PERSPECTIVE ReCOMMENDATION

\begin{tabular}{|c|c|c|c|c|}
\hline \multirow{5}{*}{ 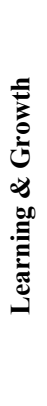 } & \multicolumn{2}{|r|}{ Strategic Objectives } & KPI & How To Calculate \\
\hline & $\mathrm{L} 1$ & Improve IT Performance & IT Plan Maturity Level & Audit by Corporate IT \\
\hline & \multirow{2}{*}{$\mathrm{L} 2$} & \multirow{2}{*}{$\begin{array}{c}\text { Increase Human Capital } \\
\text { Competency }\end{array}$} & Fit Cadre & Internal Assessment \\
\hline & & & Employee Competency Index & Internal Assessment \\
\hline & L3 & Increase Effective Organization & $\%$ Increase in Employee Productivity & Measured by Corporate HR \\
\hline
\end{tabular}

With these mappings, it is necessary to build a cascading process supporting a Segment-B strategy group.
Just as with corporate, the strategy must be used by the B segment to fulfill the corporate vision. See Fig. 5.

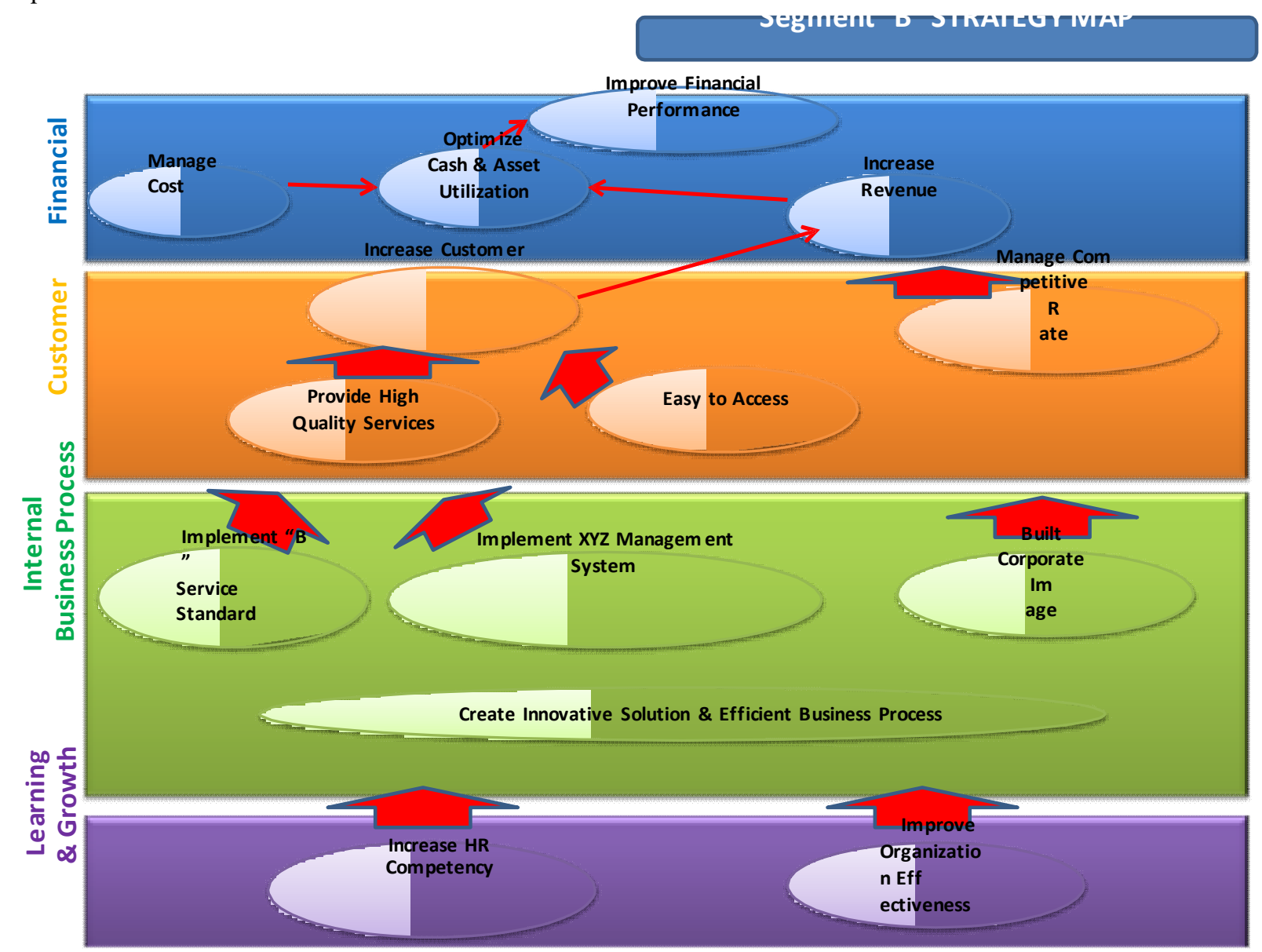

Fig. 5. Recommended Segment-B strategy map.

Tables 5 through 8 describe the strategic objectives and KPIs of Segment B. Notice that there are few differences between corporate and Segment-B strategy maps. Whereas it reflects a top-down approach, not all KPIs can cascade to all organizations, because corporate's strategy map is created based on a full-service model. Segment B comprises budget-hotels that offer fewer amenities and services. Therefore, different value propositions and strategies required. 
TABLE V. X XYZ Segment-B Strategy Map, Financial Perspective Recommendation

\begin{tabular}{|c|c|c|c|}
\hline \multirow{10}{*}{ 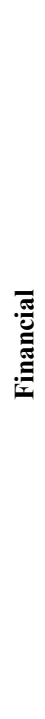 } & \multicolumn{2}{|r|}{ Strategic Objective } & KPI \\
\hline & & \multirow{3}{*}{ Increase Revenue } & Total Revenue \\
\hline & F1 & & Room Revenue \\
\hline & & & Other Revenue \\
\hline & \multirow{3}{*}{$\mathrm{F} 2$} & \multirow{3}{*}{ Manage Cost } & Operation Expense \\
\hline & & & Room Expense \\
\hline & & & Other Expense \\
\hline & F3 & Improve Financial Performance & GOP Margin \\
\hline & \multirow[b]{2}{*}{$\mathrm{F} 4$} & \multirow{2}{*}{ Cash Optimalization \& Asset Utilization } & Net Opt Cash Flow \\
\hline & & & AR Days \\
\hline
\end{tabular}

TABLE VI. XYZ Segment-B Strategy Map, Customer Perspective ReCOMmendation

\begin{tabular}{|c|c|c|c|}
\hline \multirow{10}{*}{ 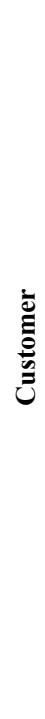 } & \multicolumn{2}{|r|}{ Strategic Objective } & KPI \\
\hline & \multirow{3}{*}{$\mathrm{C} 1$} & \multirow{3}{*}{ Increase Customer } & Occupancy Rate \\
\hline & & & Number of Membership \\
\hline & & & Number of Customer - Corp Acc \\
\hline & \multirow{2}{*}{$\mathrm{C} 2$} & \multirow{2}{*}{ Manage Competitive Rate } & Average Room Rate \\
\hline & & & Market Price Index \\
\hline & \multirow{3}{*}{$\mathrm{C} 3$} & \multirow{3}{*}{ Provide High Quality Services } & Customer Satisfaction Index \\
\hline & & & Account Satisfaction Index \\
\hline & & & Repeater Guest \\
\hline & $\mathrm{C} 4$ & Easy Access & Pick Up Service Availability \\
\hline
\end{tabular}

TABLE VII. XYZ Segment-B Strategy MaP, Internal Business Process Perspective Recommendation

\begin{tabular}{|c|c|c|c|}
\hline \multirow{6}{*}{ 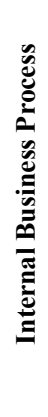 } & \multicolumn{2}{|r|}{ Strategic Objective } & KPI \\
\hline & $\mathrm{P} 1$ & Create Hotel Image & Number of Publication \\
\hline & $\mathrm{P} 2$ & Implement "B" Service Standard & "B" Service Standard Implementation Index \\
\hline & P3 & Implement XYZ Management System & XYZ Management System Implementation Index \\
\hline & \multirow[b]{2}{*}{ P4 } & \multirow[b]{2}{*}{ Create Innovative Solution \& Efficient Business Process } & NQI \\
\hline & & & Number of Innovation \\
\hline
\end{tabular}


TABLE VIII. XYZ Segment-B StRAtegy Map, LEARning \& Growth PersPective Recommendation

\begin{tabular}{|c|c|c|c|}
\hline \multirow{4}{*}{ 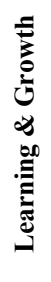 } & \multicolumn{2}{|r|}{ Strategic Objective } & KPI \\
\hline & \multirow{2}{*}{ L1 } & \multirow{2}{*}{ Increase HR Competency } & Fit Cadre \\
\hline & & & Employee Competency Index \\
\hline & $\mathrm{L} 2$ & Increase Effective Organization & \% Increase In Employee Productivity \\
\hline
\end{tabular}

From the financial perspective, the scorecard does not provide KPIs for food and beverage revenues, nor do they show expenses. For segment-B hotels, food and beverages are not provided. All other KPIs cascade. From the customer perspective, not all KPIs and strategic objectives cascade to Segment B, and only corporate deals with travel agents and reservations. Both score cards contain KPIs for measuring customer satisfaction. However, the two groups use different scoring parameters. The Appendix shows that corporate's evaluation survey is more comprehensive than Segment B's. This differentiation reflects differences in the

value propositions and business processes between hotel types.

\section{CONCLUSION}

The PT XYZ strategy development process needs improvement. The strategy map does not currently provide a BSC. The strategy map does not illustrate cause-andeffect relationships among perspectives that are otherwise commonly found on a strategic map. We found that the customer perspective is unable to describe the value offered guests by the PT XYZ. Whereas the Segment-B scorecard cascades from corporate using a top-down approach, not all KPIs and objectives flow down, because Section-B hotels offer different customer value proposition than corporate. Thus, they serve different customer segments with slightly different business models. Thus, few new strategic objectives and KPI adjustments are needed in building the Segment-B scorecard. It is thus necessary to make some adjustments to the cascading process. We therefore provide the following suggestions. First, PT XYZ should revise their strategy map. They should also implement a cascading process based on segmentation and stakeholders. Lastly, they should perform periodic reviews of their strategic map and business processes.

This research is far from perfections. $\mathrm{XYZ}$ is a private company so authors needs to reprocessed many of the data needed for this research from many internal souces since not every data are open to public. This research also discuss only on cascading on Segment "B" hotel which

some readers might found inadequate to see the whole cascading process on the company. Authors recommends further research to learn about the cascading process on a company with different types of business.

\section{REFERENCES}

[1] Badan Pengembangan dan Pembinaan Bahasa Kementerian Pendidikan dan Kebudayaan. (2012). Dipetik July 28, 2016, dari kbbi.web.id: http://kbbi.web.id/usaha

[2] Kaplan Financial Limited. (2012). Kaplan Financial Knowledge Bank. Quoted on May 7, 2019, from http://kfknowledgebank.kaplan.co.uk/KFKB/Wiki\%20Pages/The\% 20Balanced $\% 20$ Scorecard.aspx

[3] Norton, R. S. (2008). The Execution Premium. in R. S. Norton, The Execution Premium. Boston: Harvard Business Press.

[4] Omalaja M.A., E. O. (2011). Strategic Management Theory: Concepts, Analysis and Critiques in Relation to Corporate Competitive Advantage from the Resource-based Philosophy. Economic Analysis , 59 - 77.

[5] II, J. A., \& Richard B. Robinson, J. (2009). Strategic Management : Formulation, Implementation, and Control. New York: McGrawHill.

[6] Carpenter, M. A., \& Sanders, W. G. (2009). Strategic Management: A Dynamic Perspective. New Jersey: Pearson Education, Inc.

[7] Wheelen, J. D. (2000). Strategic Management, Seventh Edition. in J. D. Wheelen, Strategic Management, Sevent Edition. New Jersey: Prentice Hall.

[8] Norton, R. S. (2000). Put Strategy Into Action: Balanced Scorecard. in R. S. Norton, Put Strategy Into Action: Balanced Scorecard (hal. 16). Jakarta: Erlangga.

[9] Sunu, G. M. (Player). (2017). CT \& SMO Role. Jakarta, DKI Jakarta, Indonesia.

[10] Norton, R. S. (2004). Strategy Maps. Boston, Massachusetts: Harvard Business School Press.

[11] Norton, R. S. (2006). Alignment: Using The Balanced Scorecard to Create Corporate Synergies. Boston, Massachusetts: Harvard Business School Press. 